\title{
Demographic Background for Development of Ukraine and Italy Pension Systems
}

\author{
Nataliya Rad \\ Head Department of the Pension Fund \\ Ukraine in Donetsk region, Vice-Chief, $P h D$ \\ Donetsk, 83001, Ukraine \\ Tel. (+380) 50 6663021, E-mail: NRad2@yandex.ru
}

\section{Doi:10.5901/ajis.2013.v2n9p81}

\section{Abstract}

Certain aspects of forming present-day Ukraine and Italy pension systems have been analyzed. It is noted that basic pension security mechanism is not only a diversified source for pension payment formation but also employs a high potential for formation of national investment resources, financial market development and growth of economic activity. The study is based on the confirmation that there is relationship between effective operation of pension system and the country's demographics. Within the scope of work demographic data were collected, generalized and grouped in the context of pension systems under consideration. On the basis of comparison study of the main macroeconomic, social and economic indicators existing differences, similar problems and adverse trends related to basic pension security development have been identified. It is emphasized that solution of these problems shall be by means of settlement of social development system imbalances. Necessity for generating predictive demographic trends in the long-term is regarded. As part of the study a complex of general scientific and statistical methods was used, such as data generalization, grouping and comparison. Abstractive generalizations and conclusions were being drawn in terms of logical method. Proposals have been developed for improvement of the concept of present-day pension systems of the countries under consideration for the purposes of further social and economic development of Ukraine and Italy towards accomplishment of social tasks.

Keywords: pension system, social welfare state, tasks, demographics, basic pension security, pension, problems, trends, development, society

\section{Introduction}

Problems of moneyed assistance for elderly people take one of the most important places in the modern society. Its development corresponds to socialization of economics and rise in social consciousness of citizens. It stipulates necessity to raise the social standards of retirement income. However, these tasks require significant financial resources. They can be funded from different sources using different mechanisms of moneyed assistance. This duty can be entirely taken by a state or carried out at the expense of an employer as well as special conditions can be created for citizens to save up pensions. In modern conditions the most effective are considered mixed pension systems which combine in different ways referred to above types of retirement assets. Mixed variants give possibility to diversify sources of pension resources (Verkhovna Rada of Ukraine, 2013; The Official Website of the U.S. Social Security Administration, 2013). And with it pension systems encounter a number of problems that considerably influence mechanism of contemporary pension relations. Cardinal problems include negative (as it understood traditionally) tendencies of demographic development. Growth of elderly population in the general structure of population is referred to considerable threats of financial sustainable development of pension systems, particularly in Ukraine and Italy that requires consecutive and thoughtful analysis.

Kapitsa I., Kotlikoff L., Burns S., Kapitsa S., Libanova A. and many other authors gave consideration to the nature, point and peculiarities of retirement income in their works. However, pension systems of the investigated countries continue developing in conditions of unstable transforming society environment. That's why demographic constituents require further consecutive analysis, assessment and harmonization with pension systems development. This explains topicality of this research. Thus, the main object of this article is analysis of separate aspects of pension systems in Ukraine and Italy by means of their demographic description, bringing to light all kinds of problems and development of directions to improve the concept of pension system in the movement of further social-economic progress. 


\section{Research hypothesis}

consists in affirming possibility to minimize influence of demographic problems on pension systems 'perspectives according to peculiarities of their functioning in the current period.

\section{Research methodology}

The research is made on the basis of system approach using general scientific methods: generalization, comparative analysis. Abstract logical method was used to draw conclusions.

\section{Problem description}

Pension system depends on a number of factors of social and economic development. It is commonly believed that they are based on demographic imperative. Author Rudik V. expresses a thought that exactly demographic factors determine the level of pensioners' material security in the network of pay-as-you-go pension system (Rudik, 2011). Indeed, concept of pension system demographic imperative concedes balanced development of pay-as-you-go pension system only on the assumption of following particular (optimal - auth.) correlation between elderly and young population. However this indicator is rather specific. Estimating it the level and peculiarities of the country development as well as inherent rules, customs and traditions (influencing demography) should be taken into account. One can agree to author Semenova V. who states that it is precisely the society that sets up regulatory parameters of person's age. It stipulates specific totality and structure of possibilities at each stage of age development and specific needs to person's way of life (Semenova, 2009). Indeed, although economic activity of a person is determined by the labour field attributes, living conditions, environmental conditions, level of public health, other reasons, however, only society puts a person into the category of able-bodied or dependent citizens.

To develop mentioned before it is appropriate to underline that modern stage of social progress has considerably transformed the plane of employment relationship. Instead of production requiring hard physical labour nowadays economic activity is mainly focused on nonproductive spheres requiring first of all high level of knowledge. It means that the problem of physical wearability (to define parameters of human organism aging and its working ability) isn't as important as it was before. It gives possibility to examine categories of economically active and retirement age population more attentively. There are a lot of definitions of economically active population. Some of them are presented in table 1.

Table 1. Definition of "economically active population"

\begin{tabular}{|l|l|}
\hline $\begin{array}{l}\text { Author (source) of category } \\
\text { definition }\end{array}$ & \multicolumn{1}{c|}{ Definition } \\
\hline $\begin{array}{l}\text { Big encyclopedia of economics } \\
\text { (Varlamova, 2007). }\end{array}$ & $\begin{array}{l}\text { It is a category of population that offers its labor force for manufacturing process } \\
\text { in exchange for emolument }\end{array}$ \\
\hline $\begin{array}{l}\text { Demographic encyclopedia } \\
\text { Valentey, 1985). }\end{array}$ & $\begin{array}{l}\text { Economically active population is a part of population engaged in generally } \\
\text { useful activity bringing in return }\end{array}$ \\
\hline $\begin{array}{l}\text { Economic statistics (Ivanov, } \\
2006)\end{array}$ & $\begin{array}{l}\text { Economically active citizens are persons engaged in economic activity that brings } \\
\text { in return: (employed) and unemployed. According to the concept of labor force it } \\
\text { is a population between the ages of 15 and 70 years old ensuring supply of } \\
\text { labour to make products and services for a certain period of time. }\end{array}$ \\
\hline
\end{tabular}

Given definitions bear testimony to different approaches to understand this category in terms of economic activity potentiality and its practical implementation. It should be mentioned that to assess pension system these two approaches must be differentiated and their implementation should be discussed. We think that in the movement of pension system development, economically active population is a category of population of definite age limits. In the course of these limits it maintains possibility to carry out generally useful (economic) activity bringing in return liable to premiums according to pension legislation. Adequate determination of economically active age (of population) can be considered the basis to form the level of retirement age.

It is important to mention that there are also a lot of treatments in definition of "retirement age". Some of them are given in table 2. 
Table 2. Definition of "retirement age"

\begin{tabular}{|l|l|}
\hline Author (source) of category definition & Definition \\
\hline Finances: Glossary (Batler, 1998). & $\begin{array}{l}\text { Age at which pension is started to be paid regardless } \\
\text { of whether a pensioner stopped or continue working }\end{array}$ \\
\hline Demographic encyclopedia (Valentey, 1985a). & Age at which old-age pension is fixed. \\
\hline
\end{tabular}

It can be stated that category pensionable age is used as a rule as a conditional test for working capacity of adults achieved the moment when they are dispensed from working (by the state) and are considered conditionally disabled. It is important to mention that in conditions of multilevel (mixed) pension system concept "pensionable age" loses its direct meaning. Besides modern pension system in the network of state retirement programs provides "disability pension", "survivor's pension" that considerably pushes the envelope of present definition. In the network of mixed pension system where responsibility for pension assets is divided between the state, an employer and a person they all have their own criteria to define concept "pensionable age" that is shown in table 3.

Table 3. Principal criteria of pensionable age

\begin{tabular}{|l|l|l|}
\hline $\begin{array}{l}\text { Member of } \\
\text { pension relations }\end{array}$ & Ratable criterion & $\begin{array}{l}\text { Tendency to growth } \\
\text { (reduction) }\end{array}$ \\
\hline State & Development of economy. Financial ability to provide pensioners & Growth \\
\hline Employer & Younger age labour requirements (physical and intellectual). & Reduction \\
\hline Person & Ability to do the work, income level & Reduction \\
\hline Society & Readiness of young population to support elderly citizens & Growth \\
\hline
\end{tabular}

Source: The author's definition

Attention is drawn to different interests of pension relations ' participants in the network of given concept. Society and the state express desire to raise the pensionable age. Employer is interested in exploiting of more productive (younger) worker. Person himself (herself) first of all defines this criterion according to his (her) physical state and ability to do the work on a level with young workers. That's why, from our point of view, concept of pensionable age should reflect all specified criteria as a complex. To our mind, it can be formulated as population age at which person cannot do the work (physical or intellectual) on a level of necessary requirements and the state fixes critical degradation line (excluding his/her ability to perform professional duties). It finances moneyed assistance to support person's needs and society expresses the willingness to maintain this group of people at the expense of working population (subject to determinate conditions). An opinion is passed that optimal retire age is the age at which on other equal status there isn't transfer of income between generations. According to calculations optimal pensionable age is 64,7 years - in Italy (2006), 57,9 years - in Ukraine. Calculating in prolonged perspective up to 2045 - 2050 - correspondingly 68,7 and 62,9 years (Londar \& Bashko, 2011).

It is appropriate to underline that using this summarized characteristic of pensionable age it isn't possible to cover and take into account all individual peculiarities of people in the network of their economic activity and pension relations. According to this author Nazarov V. considers the principal problems of pension system are pension legislation shortcomings regulating comparatively not high level of retirement age (as against other European countries - auth.). Even so demographic condition of the country is estimated as moderately favorable (Nazarov, 2010). Author Libanova E. characterizes prevailing age tendencies in Ukrainian structure of population as "progressing demographic aging" (Libanova, 2012). Along with it authors Kotlikoff L. and Burns S. in their "demographic quadrant" assessed present situation and perspectives of demographic development of postsoviet countries negatively. Such facts as low birth rate and high death rate give occasion to put these countries into the category of "dying out". The authors think that Italia as majority of European countries ranges with "feeble quarter", that is swiftly aging countries. They are notable for low birthrate and high life interval (Kotlikoff \& Burns, 2004). Highlights defining demographic situation and labour-market in Ukraine and Italy are given in table 4. 
Table 4. Demography and Labor Markets Parameters in Ukraine and Italy in 2012-2013

\begin{tabular}{|l|c|c|}
\hline \multicolumn{1}{|c|}{ Parameters/ Country } & Ukraine & Italy \\
\hline Population (million) & 44,6 & 61,5 \\
\hline Age Distributions (\% of population) & 100,0 & 100,0 \\
\hline 0-14 years & 13,9 & 13,8 \\
\hline 15-24 years & 12,1 & 9,9 \\
\hline 25-54 years & 45,0 & 43,2 \\
\hline 55-64 years & 13,5 & 12,3 \\
\hline 65 years and over & 15,5 & 20,8 \\
\hline Median age (total), years & 40,3 & 44,2 \\
\hline Median age (male), years & 37,1 & 43,0 \\
\hline Median age (female), years & 43,5 & 45,3 \\
\hline Population growth rate, \% & $-0,63$ & 0,34 \\
\hline Life expectancy at birth (total population), years & 68,93 & 81,95 \\
\hline Life expectancy at birth (male), years & 63,41 & 79,32 \\
\hline Life expectancy at birth (female), years & 74,8 & 84,73 \\
\hline Expectancy population at 2050, million & 39,3 & 41,2 \\
\hline Labor force (million) & $22,06(2012$ est.) & 25,28 (2012 est.) \\
\hline Labor force by occupation, (\%): & $100,0(2012$ est.) & $100,0(2011$ est.) \\
\hline - agriculture, \% & $5,6(2012$ est.) & 3,9 (2011 est.) \\
\hline - industry, \% & 26,0 (2012 est.) & 28,3 (2011 est.) \\
\hline - services, \% & 68,4 (2012 est.) & 67,8 (2011 est.) \\
\hline Unemployment (\% of workforce), & 7,4 (2012 est.) & 10,9 (2012 est.) \\
\hline
\end{tabular}

Source: Central Intelligence Agency (2013)

Attention is paid to the fact that each of investigated countries has its own historical background of social development modern demographic constituent. However, analyzing reduced rates certain similarity can be noted first of all in such base demographic elements as the age structure of a population and labour-market structure. Unemployment rate doesn't differ much (3,5\%). The main difference in demographic situation is life expectancy rate which in Italy exceeds by 13,02 years the similar one in Ukraine. Especially negative common feature of analyzed countries is expected considerable depopulation of the investigated countries by 2050. These pessimistic predictions must result in important influence on the principal conceptual regulations of analyzed countries pension systems. It's important to take into account that population forecasts are usually drawn up subject to birth rates, death rates (migration rates, others - auth.) and using different methods, for example (Kapitsa, 2008):

$$
P_{n}=P_{0} \times\left(1+\frac{P T}{1000}\right)^{n}
$$

where $P_{n}$ - population size in n years;

$P_{0}$ - current population size;

$P T$ - supposed changes of population size per a year.

It should be underlined that it is very important to consider all factors influencing demographic tendencies for a long perspective in conditions of mixed retirement insurance scheme. It is important to take into consideration as internal so interstate and globalization elements of influence. Thereupon, conclusions of scientist Kapitsa S. are of a great interest. He notes inaccuracy of existing earlier rules to consider Earth population just as arithmetic sum of separate, not interacting populations. On his opinion the main task of demography is to explain population upsurge subject to concrete social and economic conditions (Kapitsa, 2012). The scientist drew two conclusions. Firstly, it's devoid of sense to differentiate demographic processes according to countries in conditions of globalization. Secondly, such or such demographic tendencies don't depend on social-economic conditions to such an extent as it was considered before. It is corroborated by decline in the rate of population growth in economically developed countries when population doesn't recommence but grows old swiftly. Opposite tendency can be observed in the developing world - growth of young people in the general structure of a population. As a result of so-called "birth rate crisis" number of children per each woman is 
dramatically decreasing in developing and economically well-to-do countries. Thus, in Spain and Italy this number equals 1,20, in Germany - 1,41, in Japan - 1,37. In Ukraine this rate equals 1,09 (on an average 2,15 is required to ensure simple reproduction) (Kapitsa, 2012a). Paradox of present situation makes to broaden range of factors defining demographic descriptions. Factors determining development of demography include level of possibilities for woman`s self-actualization in the modern society. Besides, crisis of moral and family values also plays certain role in demographic situation.

However, basic research of human's nature conducted by this scientist enabled him to draw further conclusions and assert deep unity of mankind development as uniform system realizing unique properties of human mind phenomenon. The author underlines that mankind development is based on informational, collective growth mechanism that is submitted to its own internal forces defining peculiarities of demographic development in such or such period of time. He introduces the concept of demographic imperative phenomenological principle affirming that growth of population is first of all determined by internal processes of mankind development but not resources or other though significant factors. The scientist asserts that exactly this fact differs demographic imperative from popular Maltus principle that population upsurge is restricted by extra inputs. Moreover the author arrives at a conclusion that resources control (ensuring upsurge) can`t be regarded as a factor determining global demographic development (Kapitsa, 2012b). The main factors of demographic tendencies in current conditions are given in table 5.

Table 5. Main factors of demographic tendencies

\begin{tabular}{|l|l|}
\hline Factors of demography development & Description in the context of pension relations \\
\hline $\begin{array}{l}\text { Level of economic and social development } \\
\text { of a state }\end{array}$ & $\begin{array}{l}\text { Determines economic opportunity and social standards established by the } \\
\text { state }\end{array}$ \\
\hline Development of person`s consciousness & Specific laws of mankind development in terms of its mind peculiarities \\
\hline Level of society development & Determines organization of citizens moneyed assistance \\
\hline Gender characteristics & $\begin{array}{l}\text { Gender structure of population. Possibilities of woman`s development and } \\
\text { self-actualization }\end{array}$ \\
\hline Influence of globalization & Socialization and acceleration of development process \\
\hline Gene pool degradation & Natural selection inaction \\
\hline Nonfinancial factors & Crisis of morality and lowering of trust in the network of all public relations \\
\hline
\end{tabular}

Source: the author's definition

Turchin A. expanded boundaries of researches devoted to globalization consequences and their influence on demographic tendencies of development. The researcher pays attention to one of the most important risk factors of globalization influence on demographic condition. The scientist believes that improving quality of life holds up natural selection. The author establishes linkage between this circumstance and probability of mutagens cumulation, their uncontrolled influence and DNA deformation that can further genetic mutations and lead to problems of reproduction and mankind population extinction at all (Turchin, 2011).

In the context of demographic researches scientists also pay attention to nonfinancial aspects of society development. Trust is regarded as a significant factor of moral basis for demographic development. Its manifestation is felt on different levels - from trust between members of one family to trust to financial institution, legislation, law, justice, state itself as well as to principles of democracy (Kapitsa, 2012c). Lowering of trust indicates destruction of relations in the society and is an indicator of demographic problems.

It should be noted that research circles also pay attention to solidarity slackening in the network of interpersonal and intergenerational relations. In the process of postindustrial society building, aims of population demographic reproduction become more and more far from ideal. Individualism became dominant in interpersonal and intergenerational relations. Demographic, particularly reproduction behavior became regarded as a private affair (Sadova, Tsapok, \& Bidak, 2011). Thus, in conditions of deformation of principal basic constituents of demographic development concept, corresponding to modern pensions system requirements, it is necessary to change radically traditional views on cause-effect relations in demographic processes. Interrelation and interdependence of demographic profiles, economic sphere, labor-market and pension relations give possibility to find out potential of their usage in the network of mixed pension system. The main parameters of pension systems of Ukraine and Italy are presented in table 6. 
Table 6. Comparison of pension system parameters in Ukraine and Italy

\begin{tabular}{|c|c|c|}
\hline Type/Parameter/Country & Ukraine & Italy \\
\hline Type of program: & $\begin{array}{l}\text { Social insurance and social } \\
\text { assistance system }\end{array}$ & $\begin{array}{l}\text { Notional defined contribution (NDC) and social insurance } \\
\text { system }\end{array}$ \\
\hline Pension Coverage & $\begin{array}{l}\text { All citizens, foreigners, and } \\
\text { stateless persons employed } \\
\text { under labor agreements or } \\
\text { self-employed persons. } \\
\text { Voluntary coverage is } \\
\text { available. } \\
\text { Special systems for civil } \\
\text { servants, legislators, judges, } \\
\text { National Bank employees, } \\
\text { diplomats, journalists, } \\
\text { scientists, local governors, } \\
\text { and victims of the Chernobyl } \\
\text { disaster. }\end{array}$ & $\begin{array}{l}\text { NDC: All employed persons, including household employees, } \\
\text { whose insurance period began on or after January } 1,1996 . \\
\text { Voluntary coverage for contract and professional workers not } \\
\text { covered by any specific fund. } \\
\text { Mixed social insurance and NDC: All employed persons, } \\
\text { including household employees, with less then } 18 \text { years of } \\
\text { contributions as of December } 31,1995 \text {. } \\
\text { Voluntary coverage for contract and professional workers not } \\
\text { covered by any specific fund. } \\
\text { Special systems for public-sector workers and self-employed } \\
\text { persons. } \\
\text { Social insurance: All employed persons, including house-hold } \\
\text { employees, with at least } 18 \text { years of contributions as of } \\
\text { December } 31,1995 \text {. } \\
\text { Voluntary coverage for contract and professional workers not } \\
\text { covered by any specific fund. }\end{array}$ \\
\hline \multicolumn{3}{|l|}{ Retirement age: } \\
\hline Old-age pension & 60 (men and women) & $\begin{array}{l}\text { Age } 66 \text { (men and women in the public sector), age } 62 \text { (women } \\
\text { in the private sector, rising gradually to } 66 \text { by 2018). }\end{array}$ \\
\hline $\begin{array}{l}\text { Old-age pension (social } \\
\text { insurance) }\end{array}$ & - & $\begin{array}{l}\text { Age } 66 \text { (men and women in the public sector), age } 62 \text { (women } \\
\text { in the private sector, rising gradually to } 66 \text { by 2018). }\end{array}$ \\
\hline Social pension (old age) & $\begin{array}{l}\text { Age } 63 \text { (men) and age } 59 \\
\text { (women, gradually rising to } \\
\text { age } 63 \text { in 2021). }\end{array}$ & 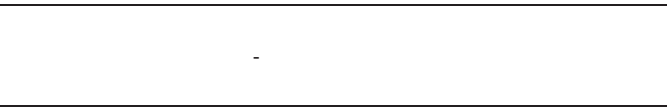 \\
\hline Social allowance & - & Age 65 \\
\hline Disability pension & Reduced age & Reduced age \\
\hline Survivor pension & $\begin{array}{l}\text { Special conditions (for } \\
\text { dependent's age) }\end{array}$ & Special conditions (for dependent's age) \\
\hline
\end{tabular}

Sources: The Official Website of the U.S. Social Security Administration (2013a)

It is indicated that pension systems of the investigated countries include different parameters of retirement insurance. Degree of their liability to the influence of demographic factors is a debatable question. Author Rudik V. believes that financial defined contributions are less susceptible to the influence of demographic factors (Rudik, 2011a). On the contrary researchers Kotlikoff $L$, Burns $S$ suggest the all-embracing character of demographic influence including financial defined contributions (Kotlikoff \& Burns, 2004a). It should be mentioned that from three systems stipulated by the concept of Ukrainian pension system financial defined contributions are still not introduced. Author's Londar S., Bashko $V$. pass an opinion that introduction of financial defined contributions can cause such positive consequences as increase of GDP growth rate. Formation of long-term resources will give possibility to raise the level of investment in economy. However up to 2045, as the authors asserts, rate of increase of national debt volume will be higher than GDP growth rate at the cost of decline in working age population, in whole debt-load will be increasing (Londar \& Bashko, 2012). It confirms that it is necessary to improve the concept of demographic development in the network of pension system development. On our opinion, the main point of necessary transformations should be based on expanding understanding of demographic processes 'driving-power. It should consist in review of main basic concepts that influence pension relations. Nowadays it is necessary to change certain social stereotypes about role descriptions of economically active population of the elderly age. Thus, minimization of population physical wearibility (professional disactualization) will enable to broaden potential of its economic activity in the network of established negative demographic tendencies. 


\section{Conclusion}

Within the framework of this research, it can be alleged, that pension systems potential isn't being unlocked in full in the analyzed countries. The research has confirmed hypothesis that pension systems of Ukraine and Italy are functioning under conditions of unfavorable demographic situation. Carried out analysis of scientific researches and publications gave possibility to extend boundaries of factors used for demographic rates and tendencies forecasting. Significant transformations in person's economic activity enable to revise boundaries of his/her economic activity. To improve efficiency of pension system in the context of existing demographic tendencies, we think, it is necessary:

1. To find out and generalize combination of factors influencing demographic development.

2. To develop multifactor methodology for long perspective demographic determinants forecasting.

3. To develop strategy for optimization of long-term demographic development taking into account a number of factors in the context of current pension system requirements.

Introduction of itemized arrangements will enable to improve efficiency of investigated countries ' pension systems in the context of social tasks solution and further social-economic development.

\section{References}

Batler, B. (1998). Finances: Glossary. Moscow, Russia: INFRA-M.

Central Intelligence Agency. (2013). The World Factbook 2013. Retrieved from http://www.cia.gov/library/publications/the-worldfactbookl

Ivanov, Yu. (2006) Economic statistics. Moscow, Russia: INFRA-M.

Kapitsa, L. (2008). Indicators of World Developmen. Moscow, Russia: MGIMO(U) (Moscow State University for International Relations). Kapitsa, S. (2012). Paradoxes of growth. Global demography and history of mankind. Moscow, Russia: Alpina confiction.

Kotlikoff, L. \& Burns S. (2004) The coming generational storm: what you need to know about america's economic future. London, England: The MIT Press Cambridge.

Libanova, E. (2012). Reasonable balance of generations is required Herald of the Pension fund of Ukraine, 11 (125), 24-27.

Londar, S. \& Bashko, V. (2011). Influence of age structure of the population on long-term pension structure equilibration. Finances of Ukraine, 10 (191), 44 - 58.

Londar, S. \& Bashko, V. (2012). Influence of age structure of the population on equilibration of government finance in Ukraine. Finances of Ukraine, 5 (198), 27 - 39.

Nazarov, V. (2010). Actual problems of pension reform. Moscow, Russia: Publishing house "Delo".

Rudik, V. (2011). Influence of demographic factors on introduction of compulsory defined contribution pension system in Ukraine. Finances of Ukraine, 1 (182), 31 - 39.

Sadova, U., Tsapok, S. \& Bidak, V. (2011). Development of social-demographic potential in the context of the second demographic transition. Regional Economy, 3 (61), $122-130$.

Semenova, V. (2009) Social dynamics of generations: problems and reality. Moscow, Russia: Russian encyclopedia of politics (ROSSPEN).

The Official Website of the U.S. Social Security Administration. (2013). Social Security Programs Throughout the World. Retrieved from http://www.ssa.gov/policy/docs/progdesc/ssptw/

Turchin, A. (2011). Structure of global disaster: Risks of mankind extinction in XXI century. Moscow, Russia: LKI.

Valentey, D. (1985). Demographic encyclopedia. Moscow, Russia: Sov. Encyclopedia.

Varlamova, T. (2007). Big encyclopedia of economics. Moscow, Russia: Ecsmo.

Verkhovna Rada of Ukraine. (2013). Act of Ukraine dd. 09.07.2003 No 1058. On Obligatory National-Level Retirenment Insurance. Retrieved from http://zakon1.rada.gov.ua 